\title{
Assessment of knowledge and attitude of radiographers towards radiation protection in Al Qassim Region, Saudi Arabia.
}

\author{
Layali Alotaibi ${ }^{1,}$ Bassam Alkhalifah², \\ ${ }^{1}$ Medical intern, graduated from Unaizah College of medicine - Al Qassim university \\ ${ }^{2}$ Assistant Professor at Unizah College of medicine, Department of Radiology- Al Qassim university
}

Background: Ionizing radiation is Important medical imaging techniques. Medical imaging is a powerful tool for diagnosis of many diseases. Although, it has potential benefits and it has harmful risks that should not be ignored.

Objective: This study aims to assessing the current knowledge and attitude toward radiation protection, radiological examination doses, and impact of radiation exposure among radiographers working in health facilities in Al-Qassim, Saudi Arabia.

Design and Setting: This cross sectional prospective survey included 100 radiographers from different governmental and private hospitals in Al-Qassim, Saudi Arabia, in the duration from October 2018 to December 2018, through self -administered questionnaires The questionnaire consisted of three sections: the first section focused on radiographers' demographic data, the second assessed the current knowledge and attitude towards radiation protection, and the third assessed the current knowledge and attitude towards radiological examination doses .

Results: Out of the 100 responders to the survey, 69 male and 31 female radiographers were included. It was observed that most of the radiographers were younger than 30 years old, with less 
than five years of experience in $54 \%$ of them. Most of the responders (84\%) had a bachelor degree or higher.

The level of education and years of experience influenced the knowledge of radiation doses especially for abdominal/pelvis CT ( $\mathrm{p}=0.016)$, thyroid isotope $\mathrm{scan}(\mathrm{p}<0.001)$ and brain MRI doses $(\mathrm{p}=0.002)$. Additionally, a significant difference was found in awareness to patient radiation protection measures $(\mathrm{p}<0.001)$ and the radiographers' opinion on the personnel who are exposed to radiation the most $(\mathrm{p}<0.001)$.

Conclusion: the current level of knowledge is inadequate. Training programs and on job training can improve the practice. Further studies with larger sample size are needed. 


\section{Introduction}

Ionizing radiation resulting from medical investigations is considered the major source of radiation doses to which the community is exposed [1]. This is mainly due to the consistently increasing need for radiological investigations especially the multi detector computed tomography (MDCT) [2]. It includes almost half the total medical radiation exposure. This has been coinciding with a tremendous advancement in imaging technology over the last few years. However, it is usually destroyed by inappropriateness and lack of optimization criteria by both referring doctors and radiographers' [3].

Ionizing radiation is carcinogenic. It can lead to drastic genetic damage that is related to cancer induction. There are many published data on the hazards of radiation regarding its cancer risk, comprising trials of the atomic bomb survivors in Hiroshima, sufferers of Chernobyl nuclear accident, and workers constantly exposed to high amount of radiation at their work, like uranium miners for instance [4].

Some epidemiological data revealed that, the least dose of X-ray radiation where there is a high probability of carcinogenicity was found to be about $10-50 \mathrm{mSv}$ for an acute exposure in addition to 50 to $100 \mathrm{mSv}$ for a prolonged exposure [5]. Therefore, the hazard of cancer development following radiation exposure depends mainly on the duration and dose of radiation exposure [6]. The classical exposure dose for performing an abdominal CT is $9 \mathrm{mSv}$ and that for a chest radiograph is $0.02 \mathrm{mSv}$. Moreover, the lifetime attributable risk (LAR) of carcinogenesis due to radiation exposure also differs in varying age groups [7]. 
Furthermore, X-ray radiation is found to have dose-dependent hazards that can cause an elevated risk of inducing cancers. This hazard in both adults and pediatrics has been targeted in most of the studies especially with the increasing number of radiological investigations, in addition to the increasing doses used [8]. Although the applications of ionizing radiation in medical imaging is clinically helpful, it is revealed that around $20 \%$ of X ray for instance are not beneficial, these and other nonessential exposures can result in 100-250 cancer cases every year in the United Kingdom [9].

The exposure of a huge number of individuals to $\mathrm{x}$-ray radiation is estimated to cause a significant number of health problems in the future. However, the adverse events are considered few for every individual [10]. Additionally, it has been found that medical workers sometimes do not have enough information on the risks of exposure to ionizing radiation and the strategies that should be followed to reduce this risk [11].

Therefore, this study aims at determining the current knowledge and attitude among radiographers toward radiation protection, radiological examination doses, and impact of radiation exposure in Al-Qassim. This will aid in implementing the right measures to enhance the level of knowledge and improve attitude through systematic education programs for radiographers and radiographers. 


\section{Materials and Methods}

\section{Study design:}

This is a cross sectional prospective survey study that included 100 radiographers from different governmental and private hospitals in Al-Qassim, Saudi Arabia, in the duration from October 2018 to December 2018. Each radiographer completed a questionnaire. The questionnaire consisted of three sections: the first section focused on radiographers' demographic data, the second assessed the current knowledge and attitude towards radiation protection, and the third assessed the current knowledge and attitude towards radiological examination doses. The study included all the participants who agreed to participate in this study. The researchers excluded the participants who refused to complete the survey.

\section{Data collection:}

Data was collected through a self-administrated questionnaire that was designed and validated after reviewing the medical literature. The questionnaire included 3 parts. The first part comprised questions about the demographics (age, sex, level of education and years of experience) of radiographers; the second and third parts included questions about the knowledge and attitude of radiographers toward radiation. Radiographers required 15 - 20 minutes to complete the questionnaire.

\section{Statistical analyses:}

Data were represented in terms of frequencies (number of patients/ cases) and valid percentages for categorical variables. Chi-square test was used to compare categorical variables between the subgroups (cross-tabulation). All P values $<0.05$ were considered statistically significant. IBM 
SPSS (Statistical Package for the Social Science; IBM Corp, Armonk, NY, USA) was used to perform all statistical calculations, version 21 for Microsoft Windows.

\section{Ethical considerations:}

Research ethical committee of health affairs of Qassim region approval was acquired prior to conducting any study procedure. Once official permission was granted, the researcher started data collection. Also, a written informed consent was taken from all the radiographers who were included in the study. The anonymity and confidentiality of the participants was completely ensured. 


\section{Results}

This cross sectional prospective survey included 100 radiographers over 14 months from different governmental and private hospitals in Al-Qassim, Saudi Arabia,. Each radiographer completed a questionnaire. Demographic data and questionnaire results are described below.

\section{$\underline{\text { Demographic data }}$}

Of the 100 responders to the survey, 69 male and 31 female radiographers were included, their age ranged between 20 to 50 years old. Age was classified into three age groups, most of the responders $(58 \%)$ were from the youngest age group (20 to 29 years old ) while only $8 \%$ from responders were from the oldest age group (40 to 49 years).

Level of education and years of professional experience were also evaluated. Most of the included radiographers $(84 \%)$ had a bachelor degree or higher, while almost half of them (54\%) were still juniors with years of experience between 1 and 4 years.

Additionally, radiographers were asked about their exposure to ionizing radiation and $68 \%$ of them were exposed to radiation through their practice several times a day. Demographic data and characters of responders are further detailed in table 1. 
Table1. Demographic data and characters of responding radiographers.

\begin{tabular}{|c|c|c|}
\hline & Count & Percent \\
\hline \multicolumn{3}{|c|}{ Gender } \\
\hline Males & 69 & 69 \\
\hline Females & 31 & 31 \\
\hline \multicolumn{3}{|c|}{ Age } \\
\hline 20-29 years & 58 & 58 \\
\hline 30-39 years & 34 & 34 \\
\hline $40-49$ years & 8 & 8 \\
\hline \multicolumn{3}{|c|}{ Level of Education } \\
\hline Associate degree & 1 & 1 \\
\hline Bachelor and higher & 84 & 84 \\
\hline Diploma or less than & 15 & 15 \\
\hline \multicolumn{3}{|c|}{ Years of Professional Experience } \\
\hline $1-4$ years & 54 & 54 \\
\hline 10-14 years & 11 & 11 \\
\hline $15-19$ years & 5 & 5 \\
\hline $5-9$ years & 27 & 27 \\
\hline More than 20 years & 3 & 3 \\
\hline \multicolumn{3}{|c|}{ Frequency of contact with imaging investigations } \\
\hline None & 6 & 6 \\
\hline several times a day & 68 & 68 \\
\hline several times a month & 14 & 14 \\
\hline several times a week & 12 & 12 \\
\hline
\end{tabular}

\section{Survey Analysis}

\section{Radiation dose for each investigation}

Radiographers were asked about the proper radiation dose for every investigation including head, thoracic, abdominal/pelvic CT, plain abdominal radiograph, abdominal ultrasound and other investigations. The responses were varying between radiographers based on their years of 
experience. Chi square analysis was done in order to know if there is a difference between responses based on years of experience. There was a difference in responses in abdominal/pelvic CT dose, thyroid isotope scan and brain MRI with P values $0.016,<0.001,0.002$, respectively.

Figure 1 shows the different responses to proper radiation dose for every indication and the comparison between different responses to the same questions based on years of experience is shown in table 2.

Figure 1.different radiographers responses to proper radiation dose required

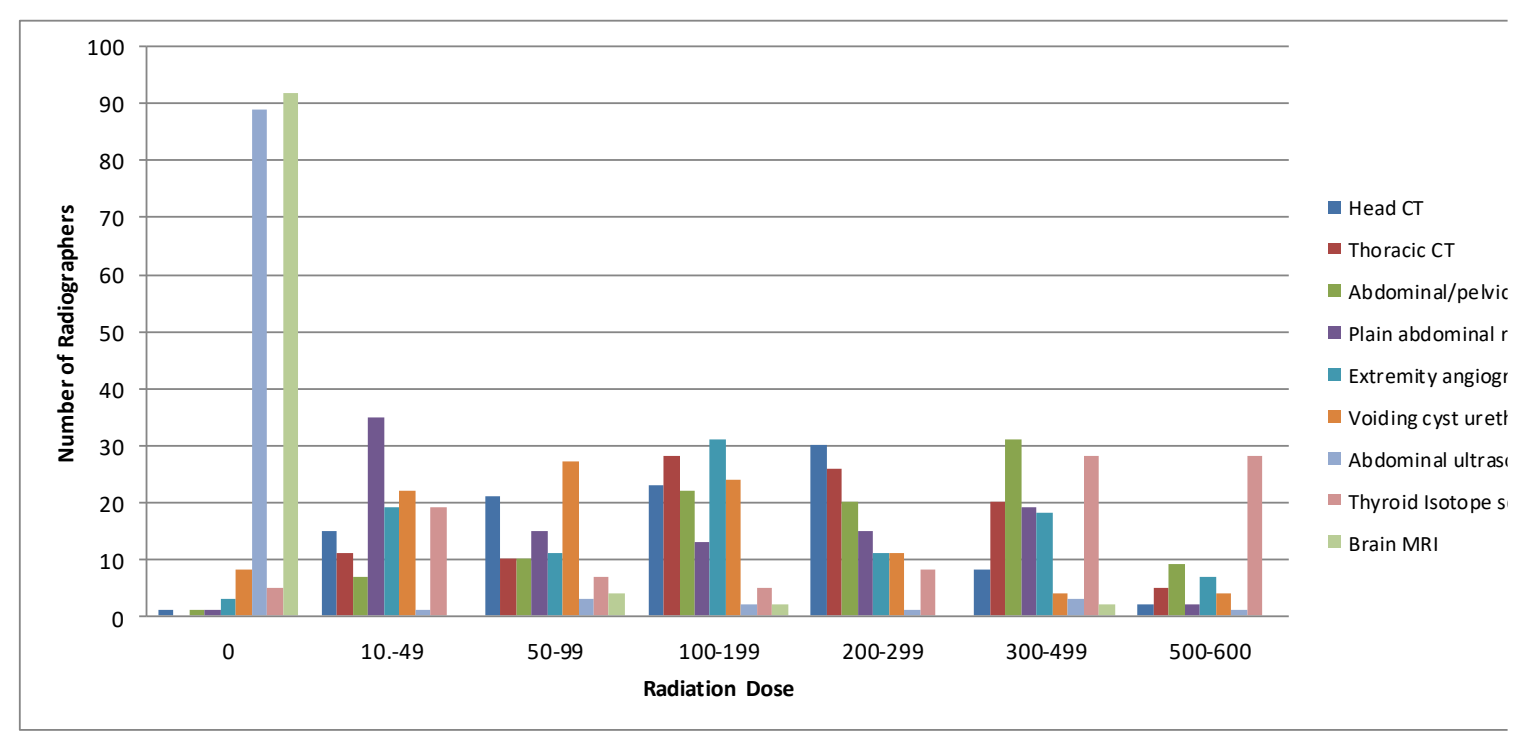


Table 2. Shows a comparison between different responses on proper radiation doses based on years of experience

\begin{tabular}{|c|c|c|c|c|c|c|c|c|}
\hline & 0 & $10-49$ & $50-99$ & $\begin{array}{l}100- \\
199\end{array}$ & $\begin{array}{c}200- \\
299\end{array}$ & $\begin{array}{c}300- \\
499\end{array}$ & $\begin{array}{l}500- \\
600\end{array}$ & P Value \\
\hline Head CT & 1 & 15 & 21 & 23 & 30 & 8 & 2 & 0.13 \\
\hline Thoracic CT & & 11 & 10 & 28 & 26 & 20 & 5 & 0.14 \\
\hline $\begin{array}{c}\text { Abdominal/pelvic } \\
\text { CT }\end{array}$ & 1 & 7 & 10 & 22 & 20 & 31 & 9 & $0.016^{*}$ \\
\hline $\begin{array}{l}\text { Plain abdominal } \\
\text { radiography }\end{array}$ & 1 & 35 & 15 & 13 & 15 & 19 & 2 & 0.643 \\
\hline $\begin{array}{c}\text { Extremity } \\
\text { angiography }\end{array}$ & 3 & 19 & 11 & 31 & 11 & 18 & 7 & 0.527 \\
\hline $\begin{array}{l}\text { Voiding cyst } \\
\text { urethrogram }\end{array}$ & 8 & 22 & 27 & 24 & 11 & 4 & 4 & 0.604 \\
\hline $\begin{array}{l}\text { Abdominal } \\
\text { ultrasound }\end{array}$ & 89 & 1 & 3 & 2 & 1 & 3 & 1 & 0.622 \\
\hline $\begin{array}{l}\text { Thyroid Isotope } \\
\text { scan }\end{array}$ & 5 & 19 & 7 & 5 & 8 & 28 & 28 & $<0.001^{*}$ \\
\hline Brain MRI & 92 & & 4 & 2 & & 2 & & $0.002 *$ \\
\hline
\end{tabular}

*Level of significance at $P$ value $\leq \mathbf{0 . 0 5}$

Tissues and populations at highest risk of radiation

Radiographers were also asked about their opinion on the organs that are most affected by radiation exposure, they had to choose between breast, bone, muscle, liver and kidney. 55\% of radiographers thought that breast is the most affected organ followed by bones (36\%). Figure 2 shows responses to different organs. Additionally, 68\% radiographers mentioned that pediatrics are at highest risk 
from exposure to radiation while $29 \%$ of radiographers mentioned that the risk is independent of age or gender.

Figure 2. Responses to different organs affected by radiation exposure.

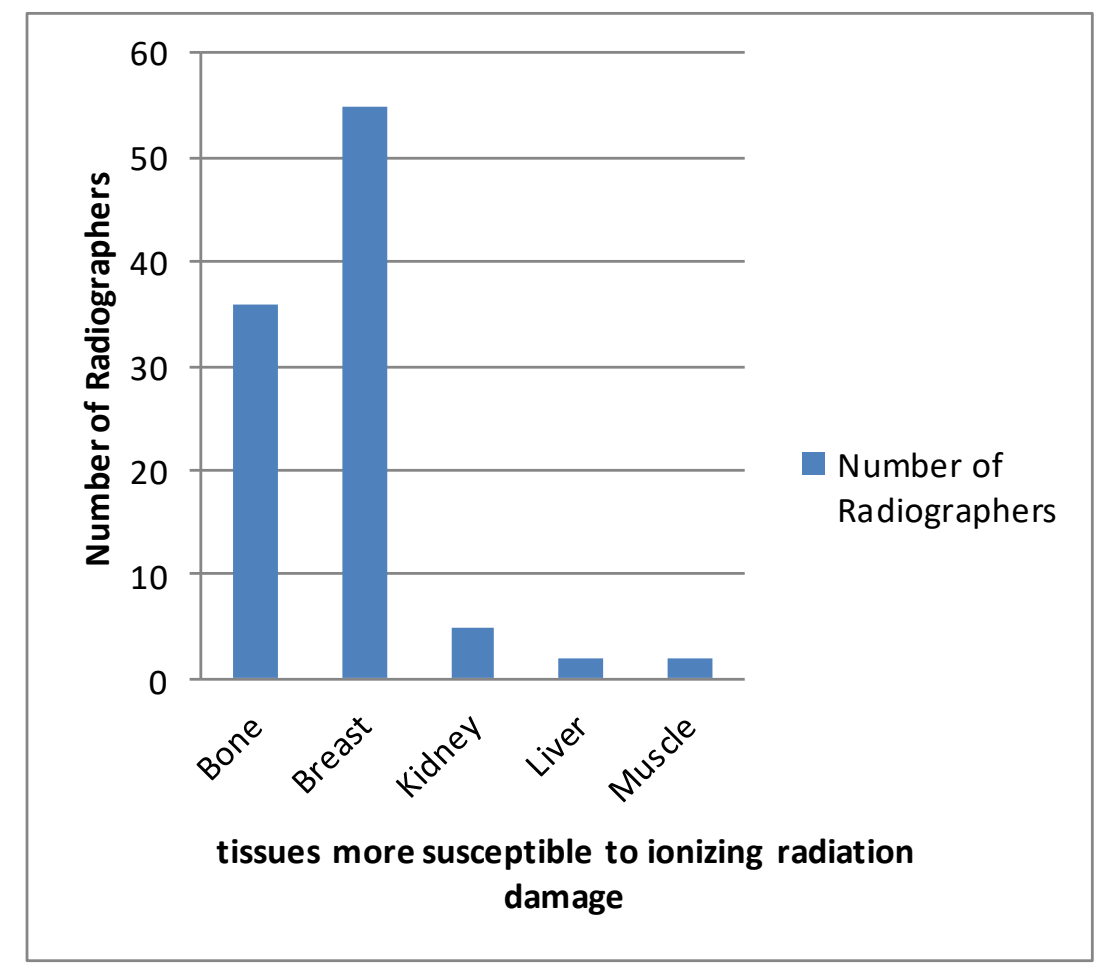

\section{$\underline{\text { Patient radiation protection measures }}$}

Radiographers were also asked about their awareness on various radiation protection measures. Lead aprons came on the top of the list with $57 \%$ of radiographers were aware of its use for patient protection, where only 2 radiographers were aware of all radiation protection strategies for patients. Figure 3 shows a description for various responses of radiographers about their awareness to radiation protection measures. 
Figure 3. shows a description for radiographers' responses on their awareness to radiation protection measures

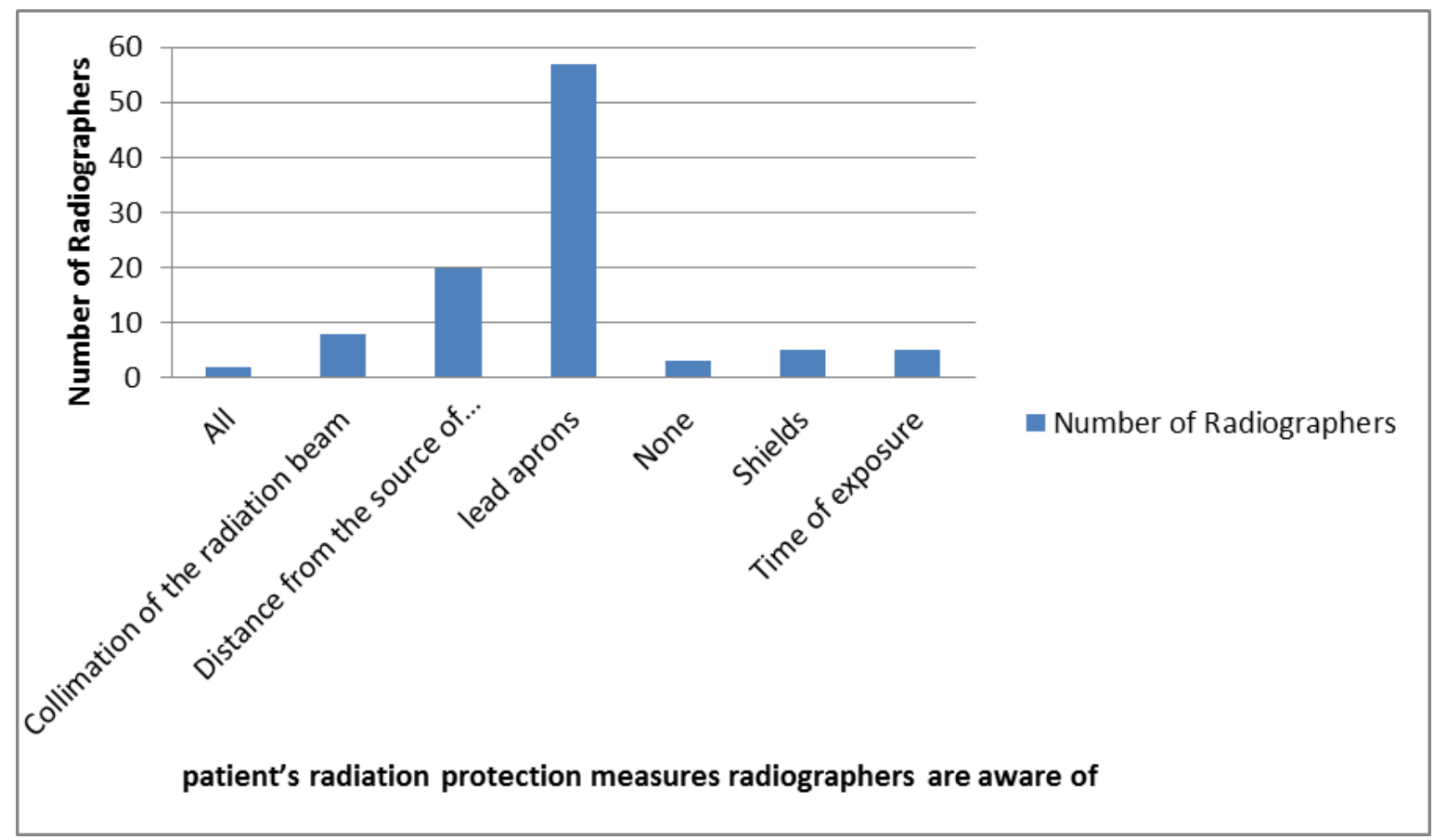

\section{Radiation exposure to working personnel}

Radiographers were asked about their opinion on the most personnel exposed to radiation. $41 \%$ responded that radiographers were the most exposed to radiation followed by nuclear medicine physicians (36\%). Surgeons were the least exposed to radiation based on only 2 responders. Moreover, radiographers were asked about the necessity of using a dosimeter and if they had attended any protection radiation programs before in addition if they think that radiation can cause cancer to patients. Different radiographers' responses are explained in table 3 
Table 3. Radiographers' responses on radiation protection questions

\begin{tabular}{|cccc|}
\hline Attending radiation & $\begin{array}{c}\text { Use of personal } \\
\text { protection course }\end{array}$ & $\begin{array}{c}\text { Radiation doses can } \\
\text { increase risk of } \\
\text { radiodosimeter for } \\
\text { radiographers }\end{array}$ & $\begin{array}{c}\text { cancer in patients } \\
\text { Yes }\end{array}$ \\
\hline No & 55 & 95 & 67 \\
\hline Don't Know & 45 & 1 & 21 \\
\hline
\end{tabular}

Responses based on years of experience and level of education

Finally, all responses to all questions included in the survey were compared using chi square test between different sub groups of years of experience which was categorized into five sub groups including ( 1 to 4 years, 5 to 9 years, 10 to 14 years, 15 to 19 years, 20 and more years). There was a difference in responses based on years of experience regarding the awareness about different radiation protection measures $(\mathrm{P}<0.001)$ and personnel at highest exposure to radiation $(\mathrm{P}<0.001)$. Comparison between different responses is shown in table 4.

Table 4. Shows comparison of responses based on years of experience

\begin{tabular}{|c|c|c|c|c|c|c|c|}
\hline & & $\begin{array}{c}1-4 \\
\text { years }\end{array}$ & $\begin{array}{c}5-9 \\
\text { years }\end{array}$ & $\begin{array}{c}10-14 \\
\text { years }\end{array}$ & $\begin{array}{c}15-19 \\
\text { years }\end{array}$ & $\begin{array}{c}\text { More } \\
\text { than } 20 \\
\text { years }\end{array}$ & P value \\
\hline \multirow{2}{*}{$\begin{array}{c}\text { Attending } \\
\text { radiation } \\
\text { protection } \\
\text { course }\end{array}$} & Yes & 26 & 15 & 8 & 4 & 2 & \multirow[t]{2}{*}{0.426} \\
\hline & No & 28 & 12 & 3 & 1 & 1 & \\
\hline \multirow{4}{*}{$\begin{array}{c}\text { Use of } \\
\text { personal } \\
\text { radio } \\
\text { dosimeter for } \\
\text { radiographers }\end{array}$} & Yes & 51 & 25 & 11 & 5 & 3 & \multirow[t]{3}{*}{0.963} \\
\hline & No & 1 & 0 & 0 & 0 & 0 & \\
\hline & Don't Know & 2 & 2 & 0 & 0 & 0 & \\
\hline & None & 2 & 3 & 1 & 0 & 0 & 0.083 \\
\hline
\end{tabular}




\begin{tabular}{|c|c|c|c|c|c|c|c|}
\hline \multirow{3}{*}{$\begin{array}{l}\text { Frequency of } \\
\text { exposure to } \\
\text { imaging } \\
\text { investigation }\end{array}$} & $\begin{array}{c}\text { Several } \\
\text { times/day }\end{array}$ & 42 & 17 & 5 & 2 & 2 & \\
\hline & $\begin{array}{c}\text { Several } \\
\text { times/week }\end{array}$ & 4 & 5 & 3 & 0 & 0 & \\
\hline & $\begin{array}{c}\text { Several } \\
\text { times/month }\end{array}$ & 6 & 2 & 2 & 3 & 1 & \\
\hline \multirow{3}{*}{$\begin{array}{l}\text { Radiation } \\
\text { dose is } \\
\text { carcinogenic } \\
\text { to patients }\end{array}$} & Yes & 29 & 23 & 8 & 4 & 3 & \multirow[t]{3}{*}{0.114} \\
\hline & No & 15 & 4 & 1 & 1 & 0 & \\
\hline & Don't Know & 10 & 0 & 2 & 0 & 0 & \\
\hline \multirow{4}{*}{$\begin{array}{l}\text { Professionals } \\
\text { more likely to } \\
\text { be exposed } \\
\text { to radiation }\end{array}$} & $\begin{array}{l}\text { Interventional } \\
\text { Cardiologists }\end{array}$ & 4 & 8 & 8 & 1 & 0 & \multirow[t]{4}{*}{$<0.001 *$} \\
\hline & $\begin{array}{l}\text { Nuclear } \\
\text { medicine } \\
\text { physician }\end{array}$ & 21 & 11 & 1 & 0 & 3 & \\
\hline & Radiographer & 27 & 8 & 2 & 4 & 0 & \\
\hline & Surgeon & 2 & 0 & 0 & 0 & 0 & \\
\hline \multirow{7}{*}{$\begin{array}{c}\text { Awareness to } \\
\text { patient } \\
\text { radiation } \\
\text { protection } \\
\text { measures }\end{array}$} & All & 2 & 0 & 0 & 0 & 0 & \multirow[t]{7}{*}{$<0.001^{*}$} \\
\hline & Collimation & 6 & 1 & 1 & 0 & 0 & \\
\hline & $\begin{array}{l}\text { Distance from } \\
\text { source }\end{array}$ & 19 & 0 & 0 & 1 & 0 & \\
\hline & Lead aprons & 23 & 20 & 9 & 4 & 1 & \\
\hline & None & 1 & 1 & 1 & 0 & 0 & \\
\hline & shields & 3 & 2 & 0 & 0 & 0 & \\
\hline & $\begin{array}{l}\text { Time of } \\
\text { exposure }\end{array}$ & 0 & 3 & 0 & 0 & 2 & \\
\hline \multirow{3}{*}{$\begin{array}{l}\text { Patients at } \\
\text { highest risk of } \\
\text { radiation }\end{array}$} & $\begin{array}{l}1 \text { year old } \\
\text { child }\end{array}$ & 35 & 20 & 5 & 5 & 3 & \multirow[t]{3}{*}{0.408} \\
\hline & $\begin{array}{l}20 \text { years old } \\
\text { female }\end{array}$ & 1 & 1 & 1 & 0 & 0 & \\
\hline & $\begin{array}{c}\text { Risk is not } \\
\text { influenced by } \\
\text { age or sex }\end{array}$ & 18 & 6 & 5 & 0 & 0 & \\
\hline \multirow{5}{*}{$\begin{array}{l}\text { Tissue more } \\
\text { susceptible to } \\
\text { radiation }\end{array}$} & Bone & 25 & 7 & 2 & 2 & 0 & \multirow[t]{5}{*}{0.572} \\
\hline & Breast & 22 & 18 & 9 & 3 & 3 & \\
\hline & Kidney & 3 & 2 & 0 & 0 & 0 & \\
\hline & Liver & 2 & 0 & 0 & 0 & 0 & \\
\hline & Muscle & 2 & 0 & 0 & 0 & 0 & \\
\hline
\end{tabular}

*Level of significance at $\mathrm{P}$ value $\leq \mathbf{0 . 0 5}$ 
Also level of education was sub categorized into three groups including Associate degree, bachelor degree and higher or diploma and less. Responses were compared over different levels of education for responders. Only responses of awareness on radiation protection measures came significantly different between different education levels with a p value $<0.001$. Table 5. Shows comparison of responses based on different educational levels.

Table 5. Shows comparison of responses based on Level of education

\begin{tabular}{|c|c|c|c|c|c|}
\hline & & $\begin{array}{l}\text { Associate } \\
\text { degree }\end{array}$ & $\begin{array}{c}\text { Bachelor and } \\
\text { higher }\end{array}$ & $\begin{array}{l}\text { Diploma or } \\
\text { less than }\end{array}$ & P value \\
\hline \multirow{2}{*}{$\begin{array}{l}\text { Attending } \\
\text { radiation } \\
\text { protection } \\
\text { course }\end{array}$} & Yes & 0 & 46 & 9 & \multirow[t]{2}{*}{0.503} \\
\hline & No & 1 & 38 & 6 & \\
\hline \multirow{3}{*}{$\begin{array}{c}\text { Use of } \\
\text { personal } \\
\text { radio } \\
\text { dosimeter for } \\
\text { radiographers }\end{array}$} & Yes & 1 & 81 & 13 & \multirow[t]{3}{*}{0.382} \\
\hline & No & 0 & 1 & 0 & \\
\hline & Don't Know & 0 & 2 & 2 & \\
\hline \multirow{4}{*}{$\begin{array}{l}\text { Frequency of } \\
\text { exposure to } \\
\text { imaging } \\
\text { investigation }\end{array}$} & None & 0 & 4 & 2 & \multirow[t]{4}{*}{0.215} \\
\hline & $\begin{array}{c}\text { Several } \\
\text { times/day }\end{array}$ & 0 & 58 & 10 & \\
\hline & $\begin{array}{c}\text { Several } \\
\text { times/week }\end{array}$ & 0 & 10 & 2 & \\
\hline & $\begin{array}{c}\text { Several } \\
\text { times/month }\end{array}$ & 1 & 12 & 1 & \\
\hline \multirow{3}{*}{$\begin{array}{l}\text { Radiation } \\
\text { dose is } \\
\text { carcinogenic } \\
\text { to patients }\end{array}$} & Yes & 1 & 55 & 11 & \multirow[t]{3}{*}{0.885} \\
\hline & No & 0 & 19 & 2 & \\
\hline & Don't Know & 0 & 10 & 2 & \\
\hline \multirow{2}{*}{$\begin{array}{c}\text { Professionals } \\
\text { more likely to } \\
\text { be exposed to } \\
\text { radiation }\end{array}$} & $\begin{array}{c}\text { Interventional } \\
\text { Cardiologists }\end{array}$ & 1 & 16 & 4 & \multirow[t]{2}{*}{0.426} \\
\hline & $\begin{array}{l}\text { Nuclear } \\
\text { medicine } \\
\text { physician }\end{array}$ & 0 & 29 & 7 & \\
\hline
\end{tabular}




\begin{tabular}{|c|c|c|c|c|c|}
\hline & Radiographer & 0 & 37 & 4 & \\
\hline & Surgeon & 0 & 2 & 0 & \\
\hline Awareness to & All & 0 & 2 & 0 & $<0.001^{*}$ \\
\hline radiation & Collimation & 0 & 8 & 0 & \\
\hline & $\begin{array}{l}\text { Distance from } \\
\text { source }\end{array}$ & 0 & 19 & 1 & \\
\hline & Lead aprons & 0 & 47 & 10 & \\
\hline & None & 1 & 2 & 0 & \\
\hline & shields & 0 & 3 & 2 & \\
\hline & $\begin{array}{l}\text { Time of } \\
\text { exposure }\end{array}$ & 0 & 3 & 2 & \\
\hline $\begin{array}{c}\text { Patients at } \\
\text { highest risk of }\end{array}$ & $\begin{array}{c}1 \text { year old } \\
\text { child }\end{array}$ & 0 & 56 & 12 & 0.293 \\
\hline radiation & $\begin{array}{l}20 \text { years old } \\
\text { female }\end{array}$ & 0 & 2 & 1 & \\
\hline & $\begin{array}{l}\text { Risk is not } \\
\text { influenced by } \\
\text { age or sex }\end{array}$ & 1 & 26 & 2 & \\
\hline Tissue more & Bone & 0 & 33 & 3 & 0.674 \\
\hline radiation & Breast & 1 & 44 & 10 & \\
\hline & Kidney & 0 & 3 & 2 & \\
\hline & Liver & 0 & 2 & 0 & \\
\hline & Muscle & 0 & 2 & 0 & \\
\hline
\end{tabular}

* Level of significance at $P$ value $\leq 0.05$ 


\section{Discussion}

In spite of the advancing applications of ionizing radiation in medical practice, it is very important to stick to high standards of radiation protection measures for both patients and medical staff safety. In addition to ensure that the medical imaging personnel are on high level of training and knowledge to guarantee a proper application for these safety measures.

In the present work, radiographers' awareness and knowledge of radiation safety and radiation doses was compared to their level of education and experience in $\mathrm{Al}$ Qassim, Saudi Arabi. It was observed that most of the radiographers were younger than 30 years old, with less than five years of experience in $54 \%$ of them. Additionally, the vast majority (84\%) had a bachelor degree or higher.

The difference in level of education and years of experience caused a significant difference of the knowledge of radiation doses especially for abdominal/pelvis CT $(\mathrm{p}=0.016)$, thyroid isotope scan $(\mathrm{p}<0.001)$ and brain MRI doses $(\mathrm{p}=0.002)$. Additionally, a significant difference was found in awareness to patient radiation protection measures $(\mathrm{p}<0.001)$ and the radiographers' opinion on the personnel who are exposed to radiation the most $(\mathrm{p}<0.001)$. 
Knowledge and experience of healthcare professionals can vary from place to another, however, survey analysis are important to take important measures to improve the overall practice. One of these surveys was done in Hong kong [12] to evaluate the knowledge and practice of physicians and interns from different specialties in a tertiary hospital about radiation exposure, the study surveyed 93 healthcare professionals and concluded that radiologists had the best scores regarding knowledge of radiation exposure though it was not as good as expected. The study concluded that knowledge of physicians was unsatisfactory which can dispose them to radiation exposure hazards and that on job training is highly recommended to improve their knowledge [12].

Another local study in Taif, Saudi Arabia [13], examined the awareness of radiographers to radiation protection in three hospitals. This study included 75 radiographers where most of them were diploma holder (54.7\%). Radiographers' ages ranged between 20 and 60 years old. This study revealed that $98.7 \%$ of the responders knew about radiation protection that walls and doors are made of lead and that wearing their dosimeters can tell the amount of radiation they are exposed to. Similarly, the study recommended continuous training and workshops to improve their knowledge on radiation protection measures [13]. 
In the present work, only personnel working in radiographer units were included. The study included 100 responders from governmental and private hospitals. Age of responders ranged between 20 and 50 years old and most of them had a bachelor degree. Our work agrees with the previous two studies in that more training and continuous workshops are essential to improve the knowledge of practioners and hence their practice. Moreover, our study examined the impact of level of education and years of experience on the knowledge about proper radiation doses for varying investigations which was not evaluated in the mentioned trials.

Medical literature didn't only investigate the knowledge of practioners, but also the awareness of medical students was also evaluated in Saudi Arabia. A study that was done in Jeddah, Saudi Arabia [14] evaluated the awareness of final year medical students on radiation hazards and protection measures. A lecture was given to the students on radiation protection strategies, followed by a multiple choice survey. Of all the students, 253 students responded to the survey. The study showed that the knowledge of final year medical students is inadequate and that they had many misconceptions about radiation doses and exposure to radiation as medical professionals. Further lectures and training is crucial for the future doctors [14].

A similar finding was recorded in an Ethiopian study [15] that was also surveying final year medical students, which can proof that reduced awareness to radiation 
exposure protection is a global alarming problem that can have terrible consequences the upcoming years.

Finally our findings are compliant with the local and international data available on knowledge about radiation exposure, where national and international training programs are essential to improve knowledge and practice of radiographers. Though our study was limited by the small sample size due to the few number of workers in the region where the study was done. To our knowledge, this study is the first of its kind in Al Qassim, Saudi Arabia. Further studies with larger sample sizes covering other areas in Saudi Arabia are essential. Additionally, patient awareness to radiation protection should also be evaluated.

\section{Conclusion}

Years of experience and level of education can have a great impact on the awareness of radiographers toward radiation doses and radiation protection strategies, though the level of knowledge is inadequate. Training programs and on job training can also improve the practice. Further studies with larger sample size and trials examining patients' awareness are needed.

\section{Acknowledgments}

Dr. Hamad Al-Amer for his role in helping at data collection. 


\section{References}

1. Ramanathan S, Ryan J. Radiation awareness among radiology residents, technologists, fellows and staff: where do we stand?. Insights into imaging. 2015 Feb 1;6(1):133-9.

2. Szarmach A, Piskunowicz M, Świętoń D, Muc A, Mockałło G, Dzierżanowski J, Szurowska E. Radiation safety awareness among medical staff. Polish journal of radiology. 2015;80:57.

3. Yurt A, Çavuşoğlu B, Günay T. Evaluation of awareness on radiation protection and knowledge about radiological examinations in healthcare professionals who use ionized radiation at work. Molecular imaging and radionuclide therapy. 2014 Jun;23(2):48.

4. Divrik Gökçe S, Gökçe E, Coşkun M. Radiology residents' awareness about ionizing radiation doses in imaging studies and their cancer risk during radiological examinations. Korean journal of radiology. 2012 Apr 1;13(2):202-9.

5. Karim MK, Hashim S, Bradley DA, Bahruddin NA, Ang WC, Salehhon N. Assessment of knowledge and awareness among radiology personnel regarding current computed tomography technology and radiation dose. InJournal of Physics: Conference Series 2016 Mar (Vol. 694, No. 1, p. 012031). IOP Publishing.

6. Singh P, Aggarwal S, Kapoor AM, Kaur R, Kaur A. A prospective study assessing clinicians attitude and knowledge on radiation exposure to patients during radiological investigations. Journal of natural science, biology, and medicine. 2015 Jul;6(2):398.

7. Al-Rammah TY. CT radiation dose awareness among paediatricians. Italian journal of pediatrics. $2016 \mathrm{Dec} ; 42(1): 77$.

8. Brown N, Jones L. Knowledge of medical imaging radiation dose and risk among doctors. Journal of medical imaging and radiation oncology. 2013 Feb;57(1):8-14.

9. Günalp M, Gülünay B, Polat O, Demirkan A, Gürler S, Akkaş M, Aksu NM. Ionising radiation awareness among resident doctors, interns, and radiographers in a university hospital emergency department. La radiologia medica. 2014 Jun 1;119(6):440-7.

10. Mojiri, Maryam, and Abbas Moghimbeigi. "Awareness and attitude of radiographers towards radiation protection." (2011): 2-5. 
11. Sin HK, Wong CS, Huang B, Yiu KL, Wong WL, Chu YC. Assessing local patients' knowledge and awareness of radiation dose and risks associated with medical imaging: a questionnaire study. Journal of medical imaging and radiation oncology. 2013 Feb;57(1):38-44.

12. Chun-sing W, Bingsheng H, Ho-kwan S, Wai-lam W, Ka-ling Y, Tiffany CY. A questionnaire study assessing local physicians, radiologists and interns' knowledge and practice pertaining to radiation exposure related to radiological imaging. European journal of radiology. 2012 Mar 1;81(3):e264-8.

13. Ahmed RM, Elamin AM, Elsamani M, Hassan WB. Knowledge and performance of radiographers towards radiation protection, Taif, Saudi Arabia. IOSR Journal of Dental and Medical Sciences (IOSR-JDMS). 2015;14(3):63-8.

14. Hagi S, Khafaji M. Medical student's knowledge of ionizing radiation and radiation protection. The Saudi Medical Journal. 2011;32(5).

15. Dellie ST, Admassie D, Ewnetu Y. An assessment of final-year medical students and interns awareness of radiation exposure to common diagnostic imaging procedures. Advances in Radiology. 2014;2014. 